\title{
Water Quality Study at Sembrong Dam Reservoir in Johor
}

\section{Halizah Awang ${ }^{1, ~ a ~}$, Zawawi Daud ${ }^{2, b}$ and Mohd Zainuri Mohd Hatta ${ }^{3, \mathrm{c}}$}

${ }^{1}$ Faculty of Technican and Vocational Education, Universiti Tun Hussein Onn Malaysia, 86400

Parit Raja, Batu Pahat, Johor Malaysia

${ }^{2}$ Faculty of Civil and Environmental Engineering, Universiti Tun Hussein Onn Malaysia, 86400 Parit

Raja, Batu Pahat, Johor Malaysia

${ }^{3}$ Faculty of Civil and Environmental Engineering, Universiti Tun Hussein Onn Malaysia, 86400

Parit Raja, Batu Pahat, Johor Malaysia

ahalizah@uthm.edu.my, bawawi@uthm.edu.my, cmzainuri88@gmail.com

Keywords: dam, water quality, chemical and biological.

Dam, reservoirs and lakes are important in the conservation of basic national resource-water. In recent years, monitoring quality of water body or reservoir has become a main concern for the determination of current condition and long-term pattern for future management. The water quality study was assessed in Sembrong reservoir located in Kluang, Johor. Water samples at each point were collected in two sampling zones, i.e. Zone A (Sembrong) and Zone B (Merpoh). In situ measurement of biological, chemical and anions and metal parameters concentration obtained from the sampling stations on Sembrong dam reservoir for determined the water quality from both zone. Result indicated Zone A was categorized as Class III according to NWQS and Zone B was classified as Class IIA/B. Besides that, Zone B was better compared Zone A in every biological and chemical concentration for water quality analysis.

\section{INTRODUCTION}

Rivers play a major role for communities especially in fisheries and as a source of water for people residing within the vicinity. Important of water quality is to cover a wide range of approaches and conflicts. Water is super abundant material on the planet, as whole, but fresh potable water is not always available at the right time or the right place for human or ecosystem use [3]. Water quality refers to the physical, chemical and biological characteristics of water. It is a measure of the condition of water relative to the requirements of one or more biotic species and or to any human need or purpose. It is most frequently used by reference to a set of standards against which compliance can be assessed. Sembrong dam reservoir was built by damming a river. When a reservoir is built along a river's flow, the physical, chemical and biological conditions of the river are disrupted to some degree [2]. Since Sembrong dam reservoir is constructed on large lowland rivers with gradually sloping banks, it can be characterized by inundation of large areas, extreme horizontal variability with extensive shallows riparian vegetation and shallow reservoir. Such reservoir is usually eutrophic and high natural organic load are likely to contribute to the formation of an anoxic hypolimnion [9]. Shallow reservoir is usually well mixed by wind, and this leads to non-stratified condition [7]. Therefore, Sembrong dam reservoir can be categorized as shallow unstratified reservoir.

\section{METHODOLOGY}

Study Area and Sampling Methods. Utilization of water and significant nearby activities is the criteria that were selected on those sampling stations. There are total of 17 water quality-sampling stations of the Sembrong dam reservoir as indicated in Fig.1. The water quality sampling stations are divided into two sampling zones, i.e. Zone A (Sembrong) and Zone B (Merpoh). 


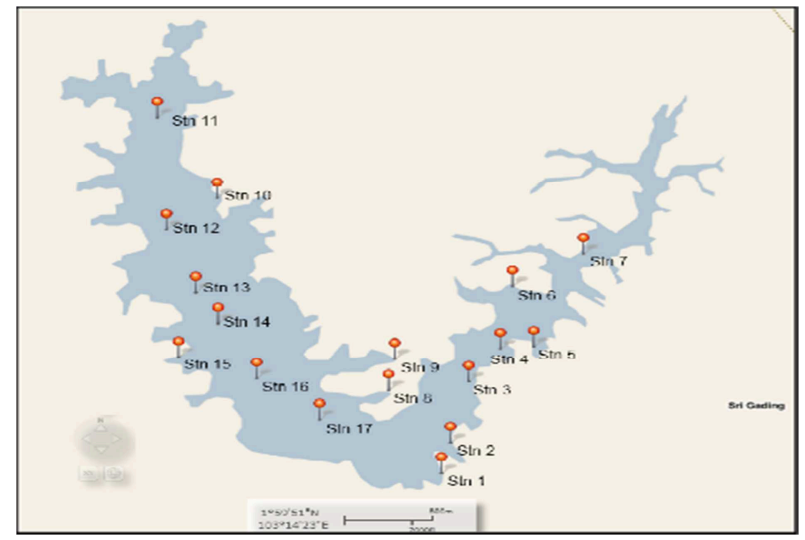

Fig. 1 Study area and sampling stations of Merpoh and Sembrong stations.

Sample Collection and Data Analysis. Water samples were collected for 17 stations. The $10 \mathrm{~cm}$ below water in that river were collected from surface water. Each samples stations water stored in one-liter polyethylene bottles. The water samples kept in ice for further analysis in laboratory. The water samples were kept in refrigerator at temperature below $4^{0} \mathrm{C}$. Parameters involved are BOD, COD, $\mathrm{N} \mathrm{H}_{3}-\mathrm{N}$, TSS and turbidity while $\mathrm{pH}$ and DO will measure directly at the station by using in-situ method due to process of obtaining the sample might change the measurement. All the result from the laboratory analysis records on the appropriate table. WQI calculates for each point using following WQI equation:

$$
\mathrm{WQI}=0.22 \mathrm{SIDO}+0.19 \mathrm{SIBOD}+0.16 \mathrm{SICOD}+(1) 0.15 \mathrm{SIAN}+0.16 \mathrm{SISS}+0.12 \mathrm{SIpH}
$$

\section{RESULTS AND DISCUSSION}

Table 2 shows water sampled in Sembrong River contains higher total coliform counts compared to Merpoh River. Total Coliform violations in the complied chlorine treated water posed problem within the water treatment plant [10]. The $\mathrm{pH}$ indicates contamination and acidification. Low $\mathrm{pH}$ allows toxic elements and compounds to become mobile. The lower the $\mathrm{pH}$, the higher the hydrogen ion $\left(\mathrm{H}^{+}\right)$activity and the more acidic is the water [6]. The neutral $\mathrm{pH}$ is considered as 7.0. Theoretically, unpolluted streams normally show a near neutral or slightly alkaline $\mathrm{pH}$. As seen from Table 2, Zone B from Merpoh shows a $\mathrm{pH}$ more neutrally rather than Zone A from Sembrong River. However, both zone are acceptable and suitable for conservation of natural environment supply because of limit from 6 to 9 . DO is an essential parameter for the survival of all aquatic organisms. Oxygen is the most well established indicator of water quality. DO test present the amount of oxygen is available in river water. From Table 2, Sembrong River station shows an average of low BOD compared Merpoh river station. Hence, low DO, high BOD and COD rapidly decrease the oxygen content of the river making it difficult for the fish and other valuable aquatic fauna to survive. Oxygen concentrations vary with the volume and velocity of water flowing in a stream. The colder the water, the more oxygen it can hold [8].

Table 3 Chemical parameter concentrations

\begin{tabular}{|c|c|c|c|c|c|c|c|c|}
\hline \multirow{7}{*}{ Zone } & $\begin{array}{c}\text { STN } \\
\text { No. }\end{array}$ & $\begin{array}{c}\text { Avrge } \\
\text { Total } \\
\text { Coliform } \\
\{\mathrm{Cfu}\}\end{array}$ & $\begin{array}{c}\text { Avrge } \\
\text { Total } \\
\text { Faecal } \\
\text { Coliform } \\
\{\mathrm{Cfu}\}\end{array}$ & $\mathrm{pH}$ & $\begin{array}{c}\mathrm{DO} \\
(\mathrm{mg} / \mathrm{L})\end{array}$ & $\begin{array}{c}\mathrm{TSS} \\
(\mathrm{mg})\end{array}$ & $\begin{array}{c}\mathrm{NH}_{3}-\mathrm{N} \\
(\mathrm{mg} / \mathrm{L})\end{array}$ & BOD (mg/L) \\
\hline \multirow{6}{*}{$\mathrm{A}$} & 1 & 97 & - & 6.71 & 4.95 & 20 & 0.16 & 2.5 \\
\cline { 2 - 10 } & 2 & 101 & - & 6.79 & 4.63 & 14 & 0.11 & 3.0 \\
\cline { 2 - 10 } & 3 & 145 & - & 6.79 & 2.25 & 16 & 0.08 & 2.0 \\
\cline { 2 - 10 } & 4 & 148 & - & 6.86 & 4.80 & 9 & 0.12 & 2.2 \\
\cline { 2 - 9 } & 5 & 175 & - & 6.89 & 4.81 & 12 & 0.17 & 4.8 \\
\hline
\end{tabular}




\begin{tabular}{|c|c|c|c|c|c|c|c|c|}
\hline \multirow{5}{*}{} & 7 & 120 & $<10$ cfu & 6.62 & 2.85 & 9 & 0.17 & 1.6 \\
\cline { 2 - 9 } & 8 & 28 & - & 6.82 & 4.88 & 59 & 0.25 & 1.3 \\
\cline { 2 - 9 } & 9 & 32 & - & 7.05 & 4.73 & 11 & 0.30 & 14.2 \\
\cline { 2 - 9 } & Avrge & 105 & $<10 \mathrm{cfu}$ & 6.82 & 4.3 & 17.2 & 0.18 & 3.73 \\
\cline { 2 - 9 } & NWSQII & 500 & $100 / 400$ & $6-9$ & $5-7$ & 50 & 150 & 3 \\
\hline A/B & & & & & & & \\
\hline \multirow{6}{*}{ B } & 10 & 32 & - & 7.02 & 5.10 & 20 & 0.19 & 2.1 \\
\cline { 2 - 9 } & 11 & 13 & $<10 \mathrm{cfu}$ & 7.89 & 5.90 & 6 & - & 2.7 \\
\cline { 2 - 9 } & 12 & 37 & - & 7.02 & 5.69 & 6 & - & 2.0 \\
\cline { 2 - 9 } & 13 & 12 & - & 6.97 & 5.09 & 5 & - & 1.0 \\
\cline { 2 - 9 } & 14 & 40 & - & 6.84 & 5.13 & 7 & - & 1.6 \\
\cline { 2 - 9 } & 15 & 33 & - & 6.81 & 5.42 & 26 & - & 3.2 \\
\cline { 2 - 9 } & 16 & 39 & - & 6.82 & 5.45 & 7 & 0.09 & 1.9 \\
\cline { 2 - 9 } & 17 & 57 & - & 6.75 & 5.81 & 6 & 0.08 & 0.8 \\
\cline { 2 - 9 } & Avrge & 33 & $<10 \mathrm{cfu}$ & 7.02 & 5.45 & 10.3 & 0.05 & 1.91 \\
\cline { 2 - 9 } & NWSQII & 500 & $100 / 400$ & $6-9$ & $5-7$ & 50 & 150 & 3 \\
\hline & A/B & & & & & & & \\
\hline
\end{tabular}

Suspended solid (SS) in water consist of inorganic and organic particles. Inorganic particles such as clay, silt and other soil constituent and organic material such as plant fibers and biological solids like algae, bacteria, plankton are found in water [10]. Sembrong River station shows a high of TSS compared Merpoh River station. Higher inorganic and organic particles in river contribute higher of TSS in river as well can effect turbidity in river water. Increasing the TSS value then increased the river to pollute.

$\mathrm{NH}_{3}-\mathrm{N}$ indicates nutrient status, organic enrichment and health of water body. It commonly forms as organic, ammonia, nitrate, nitrite and gaseous nitrogen [5]. If higher value of $\mathrm{NH}_{3}-\mathrm{N}$ recorded, then the river water considered as polluted. Result from Table 2 indicated that both river zones have a lower concentration of $\mathrm{NH}_{3}-\mathrm{N}$ from this ammonical nitrogen analysis. Merpoh River shows lower $\mathrm{NH}_{3}-\mathrm{N}$ concentration compared to Sembrong river station. Discharge of untreated sullage adds oxygen demanding substances, nutrients and toxic elements such as $\mathrm{NH}_{3}-\mathrm{N}$ into the water, which in turn make the streams unsuitable for aquatic flora and fauna [4]. As such, like any other pollution source, sullage should also be treated effectively before discharged into the streams.

BOD is the amount of oxygen required by bacteria to stabilize organic matter under aerobic conditions. The BOD test involves the determination of oxygen uptake by bacteria under standard conditions that is five days incubation at $20^{\circ} \mathrm{C}$. The concentration of BOD in water sample can determine the degree of pollution caused by microorganisms through biodegradation. If the BOD concentration is higher, then the water is considered polluted. Table 2 shows the concentration of BOD in Sembrong and Merpoh River at 17 stations involved for every sampling. Sembrong River shows high of BOD concentration compared Merpoh River. Thus, this can be classified Sembrong River as polluted. BOD is also related to DO and they are inversely proportional to each other [1].

Water Quality Index Classification. The classification of water quality of Zone A (Sembrong) and Zone B (Merpoh) followed the Water Quality Index (WQI). The DOE water quality classification based on water quality index refer on Table 4. The WQI of Sembrong River is 77.4, which is categorized as slightly polluted. Meanwhile, Merpoh River is considered clean based on the WQI of 86.9 in Table 3. 
Table 3 Water Quality Index.

\begin{tabular}{|c|l|c|c|}
\hline \multirow{2}{*}{ Zone } & \multicolumn{1}{|c|}{ Parameters } & $\begin{array}{c}\text { Sub index and } \\
\text { water quality } \\
\text { index }\end{array}$ & $\begin{array}{c}\text { Water quality } \\
\text { classification based on } \\
\text { water quality index }\end{array}$ \\
\hline \multirow{3}{*}{ A } & Biochemical Oxygen Demand (BOD) & 84.6 & Slightly polluted \\
\cline { 2 - 4 } & Ammonical Nitrogen (NH $3-N)$ & 81.6 & Slightly polluted \\
\cline { 2 - 4 } & Suspended Solids (SS) & 87.6 & Clean \\
\cline { 2 - 4 } & Water Quality Index (WQI) & $\mathbf{7 7 . 4}$ & Slightly polluted \\
\hline \multirow{3}{*}{ B } & Biochemical Oxygen Demand (BOD) & 92.3 & Clean \\
\cline { 2 - 4 } & Ammonical Nitrogen ( $\left.\mathrm{NH}_{3}-\mathrm{N}\right)$ & 95.2 & Clean \\
\cline { 2 - 4 } & Suspended Solids (SS) & 95.6 & Clean \\
\cline { 2 - 4 } & Water Quality Index (WQI) & $\mathbf{8 6 . 9}$ & Clean \\
\hline
\end{tabular}

Table 4 DOE water quality classification based on water quality index.

\begin{tabular}{|l|c|c|c|}
\hline \multirow{2}{*}{$\begin{array}{l}\text { Sub index and water } \\
\text { quality index }\end{array}$} & Clean & Slightly polluted & Polluted \\
\cline { 2 - 4 } $\begin{array}{l}\text { Biochemcial oxygen } \\
\text { demand (BOD) }\end{array}$ & $91-100$ & $80-90$ & $0-79$ \\
\hline $\begin{array}{l}\text { Ammonical Nitrogen } \\
\left(\mathrm{NH}_{3}-\mathrm{N}\right)\end{array}$ & $92-100$ & $71-91$ & $0-70$ \\
\hline $\begin{array}{l}\text { Suspended Solids } \\
\text { (SS) }\end{array}$ & $76-100$ & $70-75$ & $0-69$ \\
\hline $\begin{array}{l}\text { Water Quality Index } \\
\text { (WQI) }\end{array}$ & $81-100$ & $60-80$ & $0-59$ \\
\hline
\end{tabular}

\section{CONCLUSIONS}

As conclusion, it can be conclude that Sembrong River (Zone A) generally slightly polluted compared Merpoh River (Zone B) where is clear from pollution in Sembrong Dam. Due to Biological parameter where is Sembrong River shows high of Total Coliform rather Merpoh River. Besides that, all of chemical parameter shows that Sembrong River was not a good condition. According of Water Quality Index, Sembrong River was truly slightly polluted compared Merpoh River in Sembrong Dam.

\section{ACKNOWLEDGMENTS}

This research was supported by Ministry of Higher Education of Malaysia and scholarship from Universiti Tun Hussein Onn Malaysia. The authors are thankful for this financial support.

\section{REFERENCES}

[1] A. Akkoyunlu, M.E. Akiner: Pollution evaluation in streams using water quality indices: A case study from Turkey's Sapanca Lake Basin. (2011).

[2] C. Fera@ Nony, F. Isidore, K.H. Lee and K. Bidin: Ournal Of Tropical Biology And Conservation Vol. 10 (2013) p. 67-73.

[3] F.K. Fang, W. Easter and P.L. Brezonik: Journal of the American Water Resources Association 41(2005), p. 645-5

[4] Idris, W.N.W. Azmin, M.A.M. Som and A. Al-Mamun: The Importance of Sullage (GreyWater) Treatment for the Restoration and Conservation of Urban Streams. 1st International Conference on Managing Rivers in the 21stCentury:Issues \& Challenges Rivers 2004, 21-23 Sept 2004 
[5] M.J. Hammer and MJ. Hammer Jr.: Water and Wastewater Technology. 6th Edition. Pearson International Edition (2008)

[6] P. Davis, and R.H.M. Storm: Water management for smart growth. 1st edition. Springer Science and Business Media. (2005).

[7] R. Aggarwal, and S. Arora: INTERNATIONAL JOURNAL OF SCIENTIFIC \& TECHNOLOGY RESEARCH Vol. 1(2012), p. 52-68.

[8] Said, D.K. Stevens and G. Sehlke.Environmental assessment: Environmental Management Vol. 34 (2004), p. 406-414.

[9] T. Davie: Fundamentals of Hydrology. London: Routledge. (2003).

[10] W.A.Amneera, N.W.A. Z. Najib, S.R. M. Yusof, S.Ragunathan: International Journal of Civil \& Environmental Engineering Vol. 13 (2013) p. 1-6.

[11] www.doe.gov.my 